\title{
A STUDY OF STUDENTS' ERRORS IN USING WRITTEN PASSIVE SENTENCE
}

\author{
Achmad Anang Darmawan, M.Pd. \\ Faishol Hadi, M.Pd. \\ STKIP Al Hikmah, Jl. Kebonsari Elveka V, Surabaya, Indonesia \\ Corresponding e-mail: Sparklings7@gmail.com, \\ fayenglish.FH@gmail.com
}

\begin{abstract}
: The aim of this research is to invesitgate students' error in using English written passive sentence. The subjetcs of this research were ten second semester students of English department setudents of STKIP Al Hikmah Surabaya who took Basic English Grammar course. The objectives of this course were the students had ability in using accurate English grammar either in spoken and written for formal (scientifict and academic) or informal (daily communication) context. Passive sentence was one of grammar materials taught in this course. The objective of the material was the students were able to use passive sentence in spoken and written context. The research used descriptive quantitaive method as design of this research. The instrument of this research were documentation. The data of this research were students' work in writing sentence using accurate passive sentence. The result of this research showed many students made errors in composing passive sentence. There were 80 errors found from students' sentences. $45 \%$ errors made by the students when they could not use correct past participle on their sentence. The result also showed that $22,5 \%$ error found from students' work when they omitted be as the main component of passive sentence. There were also $17,5 \%$ errors found from students sentence in using correct be form on their sentence. $15 \%$ errors were also found based on the use of accurate singular and plural component of passive sentence.
\end{abstract}

Keywords: Passive Sentence, students' Errors

\section{INTRODUCTION}

Learning foreign language can not be separated from learning the system of the language itself or we call it as grammar.
Mastering grammar plays important for students to master language skill. Not knowing grammar in communication causes misunderstanding. Since English 
has different system of language from Indonesia, it is quite hard for students use English with accurate language system or grammar. Besides that, students difficulty in mastering English is caused by the system o native language. The goal of meaningful and understanding of language can be reached when students are able to use accurate grammar in speaking or writing. Therefore, mastering language can be reached by mastering grammar of the language.

Basic English Grammar is one of the courses that students of English department take to complete their English competence. The objective of this course is equipping the students the ability in using accurate grammar for written and spoken English activity. Some materials that students master on this course are English tenses, degree of comparison, and passive sentence. One of the material in basic English Grammar Course in passive sentence. The goal of this material is students are able to use passive rule in written and spoken English. The students are obliged to understand and apply passive structure in all kind of tenses. The way of the lecturer assesses students ability in using passive sentence is by giving them written test in composing passive sentence.

Mastering passive sentence is not easy for the ESL students since it requires other grammar competencies such us tenses mastery, use of past participle verb, and use of to be. ESL students frequently made error in making passive sentence since the did not know what type of tenses that they have to use in a sentence. Other errors that the students made were in using correct past participle and be form in passive sentence. Students' error in using past participle frequently found when their passive sentence had irregular past partciple form. Moreover, ESL students made errors of passive sentence from in using correct be form. Since they were not familiar to the use of be in a sentence, they faced problem in making correct sentence.

Based on the explanation, the writer is going to investigate students' error in using written passive sentence.

\section{LITERATURE REVIEW}

\section{Definition of Errors}

Making errors can not be avoided by the students in learning English for foreign language. One of the errors that 
the students frequently make is in using correct language system or grammar. Making errors in using language can be caused by several factors. Students' mother tongue influence become one of the factor or students' errors. Erdogan (2005:26) said that students' errors in using language are caused by their habit in using theiir mother tongue. Students' errors in using language system are also influenced by their lack of knowledge of the target language (Hubard, 1983:134). When learners make an errors caused by the lack of knowledge they can not correct it by themselves. They need learn a lot and understand then they can correct their errors. In other words errors is defined by as students inacceptable performance in using language system caused by their lack of knowledge so that they can not correct by themselves.

\section{Types of Errors}

According to James (1998), errors are classified into four types, they are:

a. Errors of Ommision

Errors of Ommission frequently appears when one of the element of the sentences is ommitted.

Example : We not visit his house yesterday
It should be: We did not visit his house yesterday

b. Errors of Addition

When the elements of the sentence are added and the addition causes inaccurate sentence structure, it is categorized as errors of addition.

Example : All mechanics are fix customers' cars every day.

It should be : All mechanics fix customers' cars every day.

c. Errors of Misinformation

Misinformation is the error of uisng one grammatical form in the place of another grammatical form.

Example : We doesn't take Principles of Language course this semester.

It should be : We don't take Principles of Language course this semester

d. Errors of Misordering

Misordering appears on the sentence when the order of the element of the sentence is incorrect.

Example : The students not did have physics examination two days ago.

It should be : The students did not have physics examination two days ago.

\section{Definition of Passive Voice}

According to Murphy

(1985:84)

passive voice is a sentence in which the 
cause of the action using by. Passive voice is a senetnce in which the doer occurs in prepositional phrase at the end or not at all. In other words the subject of the sentence in active sentence become the object in passive voice. Lim (1975:60) gives additional information about the definition of passive voice that passive is derived from active sentence and it does not change the meaning of the sentence.

In term of the form of element of the sentence, passive sentence structure is different from active sentence. The main elements used in passive sentence are in using auxiliary (be) and past participle form (be + past participle). The form of passive voice is also influenced by sentence tenses. The pattern of the passive voice based in each tenses is explained from the following table (Thomson and Martinet):

Table 1

\begin{tabular}{|l|l|}
\hline Tenses & \multicolumn{1}{|c|}{ Passive } \\
\hline Simple & Is/am/are + past \\
Present & participle \\
& A glass of water is drunk \\
& by Ali every morning \\
& The shoes are usually \\
& polished by him every \\
& Sunday. \\
\hline
\end{tabular}

\begin{tabular}{|c|l|}
\hline Present & Is/am/are + being + past \\
Progressive & $\begin{array}{l}\text { participle } \\
\text { The novel is being read by } \\
\text { my sister } \\
\text { The money is being } \\
\text { counted by bank teller }\end{array}$ \\
\hline Simple & $\begin{array}{l}\text { Was/were }+ \text { past } \\
\text { participle } \\
\text { Past }\end{array}$ \\
\hline The classroom was \\
cleaned by the students \\
yesterday. \\
The laptop was fixed by \\
my father two days ago. \\
\hline Future
\end{tabular}

\section{FINDINGS AND DISCUSSIONS}

This research used descriptive quantitative research. Matthew and Ross (2010) stated that quantitative methods are implemented in which the data of the research are 
presented using numerical form. This research was used since the data of the research need to analyzed using quantitative approach the describe it. The participants of this study were second students of English department STKIP Al Hikmah who took Basic English Grammar course. The instruments of this research were documents. The document of this research were students' work in composing written passive sentence.

The aim of this study is to investigate students' errors in using passive voice for written sentence. To know students errors in using passive sentence, the researcher gave passive sentence test to the students. The test consisted of fiften questions in which the questions represented five basic tenses in English, they were simple present tense, present continuous, simple past tense, simple future tense, and present perfect tense. The type of the question for this test was changing the active sentence into passive sentence. The data of the research, it is students' work in doing passive sentence then analyzed. In analyzing students' passive sentence error, the researcher used surface strategy taxonomy. The surface strategies were omission, addition, misformation, and misordering (Dullay's, 1982).

\section{Number of Errors Based on the Form.}

Students' errors based on the form were classified based on the following groups (Azar's, 1992):

1. Past participle

2. Be form

3. Word omission

4. Singular-plural

To know the total erros that students made in making passive sentence, the researcher used the formula which ever used by Bluman (2004). This formulas was also used to know the precentage of the errors for each error category. The following was the formula:

$$
\mathrm{N}=\frac{f x}{N} \times 100 \%
$$

$\mathrm{N}$ : The percentage of errors

FX: Number of errors for each type

$\mathrm{N}$ : Number of all errors

100\%: Constant numeral

The following was the result of the number of errors made by the srudents.

\begin{tabular}{cccc}
\hline No & Type of Erros & $\begin{array}{c}\text { Total } \\
\text { Errors }\end{array}$ & $\begin{array}{c}\text { Precentage } \\
(\%)\end{array}$ \\
\hline 1 & Past participle & 36 & $45 \%$ \\
2 & Be form & 14 & $17,5 \%$ \\
3 & Word & 18 & $22,5 \%$
\end{tabular}




\begin{tabular}{|c|c|c|c|}
\hline 4 & $\begin{array}{c}\text { omission } \\
\text { Singular- } \\
\text { plural }\end{array}$ & 12 & $15 \%$ \\
\hline & Total & 80 & $100 \%$ \\
\hline
\end{tabular}

The table above showed that there were 80 errors made by the students in composing passive sentences. The most frequent errors were found from students' errors in using correct past participle (45\% errors from 80). The second frequent errors made by the students were based on word omission component (22,5\% from 80$)$. On this error, most students omitted be as the main component of passive sentence. The third frequent errors were from in using proper be form in passive sentence (17,5\% from 80$)$. Onle some students made errors from the use of singularplural to the correct auxiliary verb $(15 \%$ from 80 errors).

\section{Errors Based on Tenses}

The followings are the findings of students' errors in composing passive sentence based on the tenses used.

1. Simple Present Tense

Simple present tense passive sentence emerged on question 4, 11, and 13. According to the students' works, five students made errors in using past participle for passive sentence. In question
11 for instance, the correct past form was taught. Unfortnately some students did mispelling for this verb, it was tought. There were two errors in using be form for this passive sentence. In question 4 for instance, the researcher found that two students used were rather than was on the sentence. Word omission errors also could be found in simple present passive sentence. The students made these errors since the omitted be on the sentence.

Question 4 : They serve the breakfast at eight o'clock every day. The correct passive sentence for this question was The breakfast is served by them at eight o'clock every day. According to the students' anwers,

Question 11 : My Green teaches the biology class every Wednesday.

Question 13 : The choir really enjoys that piece

\section{Present Continuous Tense}

There were three questions of present continuous passive sentence on the test. The followings were the questions:

Question 8 : Someone is digging the land now

Question 14 : My father is riding his motorcycle to the market now

Question 15 : All students are wearing wearing batik uniform now. 
According to the students' answer in composing past passive sentence, there were twelve errors in using past participle on the sentence. One of the examples of this erros was the student used digged for past participle usage for passive sentence number eight. This error was also found on question number 14 . The student wrote rodden rather than ridden for making passive sentence. The type of the error for this presen $t$ continuous passive could also be found from the use of be on the sentence. Most be form errors were made by the students on question 15 . The students used are for the sentence rather than the correct be, it was is. The error of word omission was also seen on continuous passive sentence. There were five errors of word omission made by the students for this type of sentence. Most errors emerged when the students omitted being for one of the main components of in compsing continuous passive sentence.

\section{Simple Past Tense}

The followings were the question for past passive sentences.

Question 1 : A thief stole my purse.

Question 12 : Millions people watched Islamic TV programme last week.

Question 5 : People threw away tones of rubbish yesterday.
There were ten errors that students made in composing past passive sentence. Two errors were found on question number 5 . The errors were seen when the students used past participle threwn fo rather than the correct past participle thrown. Six errors of be form were found from students' past passive sentences. One of the example of the error was found on question 12. The students used be were rather than using the correct one was. Word omission errors were also found from students' sentences. The students made this error omitted be on the sentence.

\section{Present Perfect Tense}

The followings are the questions for passive pefect tense sentence:

Question 10 : They have delivered my computer.

Question 3 : Ahmad has consulted his two scientific papers to Mr. Ali.

Question 9 : One of the students has watered the flowers.

The result of students' answers toward those three questions showed that eighteen errors were made by the students in composing those sentences. Six students made an error in word omission aspect. The students who made this error did not write been as the main component of 
passive perfect sentence. In other words, their sentence was incorrect since they omitted been on their sentence. The errors for passive perfect sentence could also be foud from the use singluar-plural subject to the auxiliary used on the sentence. Most twelve students made this error when they use have or has as the auxiliary of the sentence, for example for question 10 some students used have rather than has as the correct auxiliary of the sentence.

5. Simple Future Tense Question 2 : The police will arrest the robbers.

Question 6 : They will build a new bridge next year.

Question 7 : Pierre Matie will seek her cat tomorrow morning.

There were eighteen twenty errors made by the students in composing passive future tenses. Seventeen errors were found from students' sentences in using past participle. The most errors were made from question 6 and 7. On question 6 , the students used an incorrect past participle builded rather than built as the coreect past participle. On question 7, the correct past participle that students used for the sentence was sought. Unfortunately, most students used seeked as the past participle on their sentence.
Word omission errors were also made by two students in composing passive future tenses. Those two students made this error since they omitted be as the main component of passive future on their sentennce.

\section{CONCLUSION}

According to the findings of the study we could have a conclusion that many students still had a problem in composing proper passive sentence. The first biggest problem faced by the students in making passive sentence was in using irregular past participle in a sentence. The students had this problem since they were not familiar with all kinds of irregular past participle. The second biggest problem found from the findings was many students were not familiar with the pattern in using passive sentence. This error or problem were found when the students omitted be as the main component of the passive sentence. When a student made a passive sentence without inserting be as the main component of the sentence, the meaning of the sentence will be active. The use of be form was the third big problem faced by the students in making passive sentence. The finding of this study 
showed that some students could not use accurate be form for every type of tenses of the passive sentence .

\section{REFERENCES}

Dulay, H. (1982). Language Two. New York: Oxford Uniersity Press.

Erdogan, V. (2005). Contribution of error analysis to foreign language teaching. Journal of the Faculty of Education, 1(2), 261-270.

Hubard, Peter, et.al. (1983). A Training Course for TEFL. New York: Oxford University Press.

James, Carl. (1998). Errors in Language Learning and Use: Exploring Error Analysis. London: Addison Wesley Longman Limited.

Matthews, B. \& Ross, L. (2010). Research Methods. A Practical Guide for the Social Sciences. Harlow: Longman

Murphy, Raymond. (1985). English Grammar in Use. New York: Cambridge University.

Thomson, A. J., \& Martinet, A. (1986). A Practical English Grammar. London: Oxford University Press. 